\title{
Increased Expression of Nox1 in Neointimal Smooth Muscle Cells Promotes Activation of Matrix Metalloproteinase-9
}

\author{
Shaoping $\mathrm{Xu}^{\mathrm{a}}$ Amy S. Shriver ${ }^{\mathrm{a}}$ Dammanahalli K. Jagadeesha $^{\mathrm{b}}$ \\ Ali H. Chamseddine ${ }^{a} \quad K^{2}$ atalin Szőcs ${ }^{d} \quad$ Neal L. Weintraub ${ }^{a}$ Kathy K. Griendling ${ }^{d}$ \\ Ramesh C. Bhalla ${ }^{b}$ Francis J. Miller, Jr. ${ }^{a-c}$ \\ Departments of a Medicine and ${ }^{b}$ Anatomy and Cell Biology, University of lowa, and ${ }^{\mathrm{C}}$ Veterans Affair Medical Center, \\ lowa City, lowa, and ${ }^{\mathrm{d}}$ Department of Medicine, Emory University, Atlanta, Ga., USA
}

\section{Key Words}

Restenosis · NADPH oxidases • Oxidative stress •

Antioxidants

\begin{abstract}
Objective: Vascular injury causes neointimal hypertrophy, which is characterized by redox-mediated matrix degradation and smooth muscle cell (SMC) migration and proliferation. We hypothesized that, as compared to the adjacent medial SMCs, neointimal SMCs produce increased superoxide via NADPH oxidase, which induces redox-sensitive intracellular signaling to activate matrix metalloproteinase-9 (MMP9). Methods and Results: Two weeks after balloon injury, rat aorta developed a prominent neointima, containing increased expression of NADPH oxidase and reactive oxygen species (ROS) as compared to the medial layer. Next, SMCs were isolated from either the neointima or the media and studied in culture. Neointimal-derived SMCs exhibited increased Nox1 expression and ROS levels as compared to medial SMCs. Neointimal SMCs had higher cell growth rates than medial SMCs. ROS-dependent ERK1/2 phosphorylation was greater in neointimal SMCs. MMP-9 activity, as detected by gel zymography, was greater in neointimal SMCs under resting and stimulated conditions and was prevented by ex-
\end{abstract}

pression of an antisense to Nox1 or treatment with an ERK1/2 inhibitor. Conclusions: Following vascular injury, the increased expression of Nox1 in SMCs within the neointima initiates redox-dependent phosphorylation of ERK1/2 and subsequent MMP-9 activation.

Copyright $\odot 2012$ S. Karger AG, Basel

\section{Introduction}

In response to acute vascular injury, intimal hyperplasia occurs due to the migration of a subset of medial smooth muscle cells (SMCs) to the intima, where they proliferate and assume a noncontractile or synthetic phenotype [1]. Previous studies demonstrate that the SMCs in the neointimal layer are morphologically distinct from 'spindle-shaped' SMCs in the surrounding medial layer [2]. Instead, these epithelioid-shaped cells have different biological properties, including faster proliferation and expression of fewer muscle-specific markers than the spindle-shaped cells [3-6].

S.X. and A.S.S. contributed equally to this paper.

\section{KARGER}

Fax +4161306 1234

E-Mail karger@karger.ch

www.karger.com
(C) 2012 S. Karger AG, Basel

$1018-1172 / 12 / 0493-0242 \$ 38.00 / 0$

Accessible online at:

www.karger.com/jvr
Prof. Francis J. Miller, Jr.

Department of Internal Medicine, University of Iowa

285 Newton Road, Room 2269 CBRB

Iowa City, IA 52242 (USA)

Tel. +1 319334 4524, E-Mail francis-miller@ uiowa.edu 
Vascular reactive oxygen species (ROS) levels are increased following balloon angioplasty, and systemic antioxidant therapy inhibits neointima formation [7-9]. Several studies implicate NADPH oxidase as the primary source of ROS following injury $[7,8,10]$, and inhibition of NADPH oxidase reduces ROS levels and neointimal hyperplasia [11]. Redox-dependent activation of SMCs by NADPH oxidase promotes migration, proliferation, and extracellular matrix degradation $[12,13]$. We hypothesized that in response to acute injury, increased expression and activation of NADPH oxidase by neointimal SMCs promotes intracellular signaling and activates matrix metalloproteinases.

\section{Methods}

Detailed protocols are described in online supplementary materials (www.karger.com/doi/10.1159/000332958).

\section{Intimal and Medial SMC Culture}

Two weeks after balloon injury by Fogarty 2-Fr arterial embolectomy catheters [14], rat aortas were harvested and placed in Dulbecco's modified Eagle's medium (DMEM). Four-millimeter segments were obtained for superoxide detection as described below. The remaining aorta was cleaned of freely adhering tissue and cut longitudinally and the endothelium gently removed by scraping. Next, the aorta was incubated in DMEM with $400 \mathrm{U} / \mathrm{ml}$ collagenase type 4 at $37^{\circ} \mathrm{C}$ for $20 \mathrm{~min}$, and then neointimal cells were scraped and cultured separately. The remaining medial SMCs were cut into 1-mm sections and incubated in high-glucose DMEM containing $100 \mathrm{U} / \mathrm{ml}$ penicillin, $100 \mu \mathrm{g} / \mathrm{ml}$ streptomycin, $2 \mathrm{mM}$ L-glutamine, $10 \mathrm{mM}$ HEPES, $1 \times$ basal medium Eagle vitamins, $1 \times$ minimum essential media nonessential amino acids, $20 \%$ fetal bovine serum (FBS) at $37^{\circ} \mathrm{C}$ for $24 \mathrm{~h}$. Next, sections were incubated with DMEM with $400 \mathrm{U} / \mathrm{ml}$ collagenase type 4 and 1.5 $\mathrm{U} / \mathrm{ml}$ elastase at $37^{\circ} \mathrm{C}$ for $40 \mathrm{~min}$; sections were triturated to accelerate dissociation. Neointimal and medial SMCs were plated on $0.1 \%$ gelatin-coated dishes and maintained in DMEM supplemented with $10 \% \mathrm{FBS}, 2 \mathrm{mmol} / \mathrm{l}$ L-glutamine, $100 \mathrm{U} / \mathrm{ml}$ penicillin, and $100 \mu \mathrm{g} / \mathrm{ml}$ streptomycin at $37^{\circ} \mathrm{C}$ in a $5 \% \mathrm{CO}_{2}$-humidified incubator. Cells were confirmed to be $\alpha$-actin-positive by immunostaining at passage 3-4. Experiments were performed using SMCs at $70-90 \%$ confluence from passages $5-11$. When indicated, cells were serum-deprived by changing the media to DMEM containing $0.1 \%$ FBS for $24 \mathrm{~h}$. For individual experiments, the passage number was identical for medial and neointimal-derived SMCs.

\section{Superoxide Detection}

Aortic segments $(4 \mathrm{~mm})$ were rinsed in cold PBS and flashfrozen in OCT as previously described [15]. Sections $(30 \mu \mathrm{m})$ were incubated for $30 \mathrm{~min}$ in dihydroethidium (DHE, $10^{-5} \mathrm{M}$ ), and examined by fluorescent confocal microscopy (excitation at $488 \mathrm{~nm}$ and detection using a 585-nm long-pass filter). Where indicated, sections were pretreated with tiron or diphenylene iodonium $\left(\mathrm{DPI}, 10^{-4} \mathrm{M}\right)$ prior to the addition of DHE. Intracellular superox- ide was measured in cultured SMCs after incubation in DHE $\left(10^{-5} \mathrm{M}, 30 \mathrm{~min}\right)$, and fluorescence intensity was measured by flow cytometry as described [16]. Where indicated, cells were pretreated with DPI $\left(10^{-5} \mathrm{M}\right)$ or polyethylene-glycolated superoxide dismutase (PEG-SOD, 250 units $/ \mathrm{ml}$ ) prior to DHE staining. NADPHdependent superoxide was measured in membrane-enriched SMC fractions [16]. Briefly, sonicated SMCs were centrifuged $(250 \mathrm{~g}, 10 \mathrm{~min})$. The supernatant was centrifuged $(70,000 \mathrm{~g}, 1 \mathrm{~h}$, $4^{\circ} \mathrm{C}$ ), then $20 \mu \mathrm{g}$ of soluble protein was added to PBS containing lucigenin $\left(5 \times 10^{-6} \mathrm{M}\right)$ and NADPH $\left(10^{-4} \mathrm{M}\right)$ and placed in an FB12 luminometer. After a 2-min dark adaptation period, measurement of emitted light was obtained every $30 \mathrm{~s}$ and averaged over a 5 -min period.

\section{Cell Growth}

SMCs were serum-deprived in $0.1 \%$ FBS for $48-72 \mathrm{~h}$ and then incubated in $0.1 \%$ serum with ${ }^{3} \mathrm{H}$-leucine in the presence or absence of tiron $\left(10^{-4} \mathrm{M}\right)$ for an additional $24 \mathrm{~h} .{ }^{3} \mathrm{H}$-leucine incorporation was quantitated using a liquid scintillation counter, and cell growth was quantitated relative to untreated medial SMCs in $0 \%$ serum.

\section{Western Blotting}

SMCs were lysed and equal amounts of lysates were analyzed by Western blotting with antibodies against $\alpha$-actin, smooth muscle myosin heavy chain (MHC), mitochondrial (MnSOD) and intracellular (CuZnSOD) isoforms of SOD, catalase, phospho-ERK1/2, and ERK1/2.

\section{Immunohistochemical Probing of $p 47^{p h o x}$ and $p 22^{\text {phox }}$}

Snap-frozen aortae were sectioned ( $8 \mu \mathrm{m}$ thick) and probed with p $47^{\text {phox }}$ and $\mathrm{p} 22^{\text {phox }}$ antibodies.

\section{Matrix Metalloproteinase-9 Induction}

Gelatinase activity in conditioned media was assayed by gel zymography and normalized to cell number as described [17, 18].

\section{Adenoviral-Mediated Gene Transfer}

Cells were transduced with adenoviruses containing either shRNAs to Nox1 (Ad-shNoxl) or GFP (Ad-shGFP) as a control [19].

Nox1 and Nox4 mRNA Expression

Expression of Nox1 and Nox4 was assessed by quantitative RT-PCR (qRT-PCR) in SMCs and normalized to 18S rRNA.

\section{Statistical Analysis}

Results are expressed as mean \pm SEM. Statistical comparisons were performed by Student's two-tailed $t$ test or one-way analysis of variance (ANOVA) with post-hoc analysis with Tukey's multiple comparison posttests. A p value of $<0.05$ was considered significant.

\section{Results}

We first characterized the localization of ROS production within the aorta 2 weeks after balloon injury. Injured aorta formed a well-defined neointima with 
Fig. 1. Superoxide levels and NADPH oxidase expression are increased in the neointima. a-d Representative confocal fluorescence micrographs are shown of sections of thoracic aorta stained with DHE. Fluorescence intensity reflects cellular ROS levels. a Sham operated. b Two weeks following balloon injury. Sections of injured aorta were pretreated with tiron $\left(10^{-3} \mathrm{M}\right)(\mathbf{c})$ or DPI $\left(10^{-5} \mathrm{M}\right)(\mathbf{d})$ prior to DHE imaging. Representative light micrographs of sham $(\mathbf{e}, \mathbf{g})$ and balloon-injured $(\mathbf{f}, \mathbf{h})$ aorta immunostained for the NADPH oxidase subunits $47^{\text {phox }}(\mathbf{e}, \mathbf{f})$ and $\mathrm{p} 22^{\text {phox }}(\mathbf{g}, \mathbf{h})$. Sections processed without primary antibody showed no staining (data not shown). Arrows indicate internal elastic membrane.
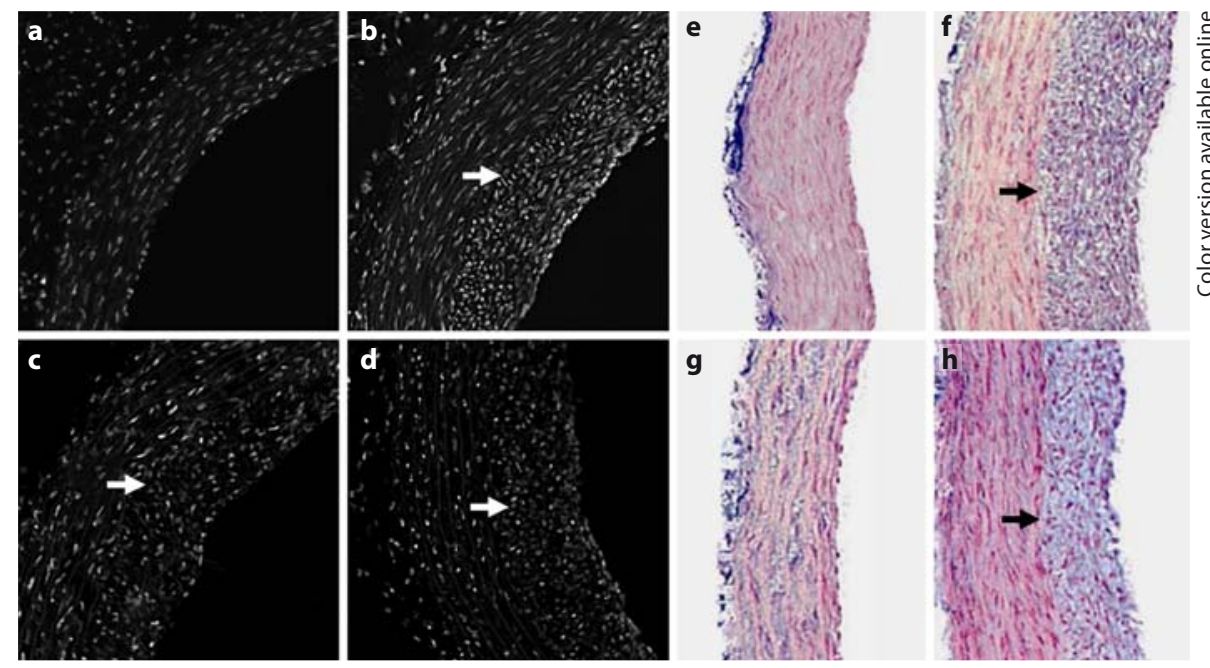

g
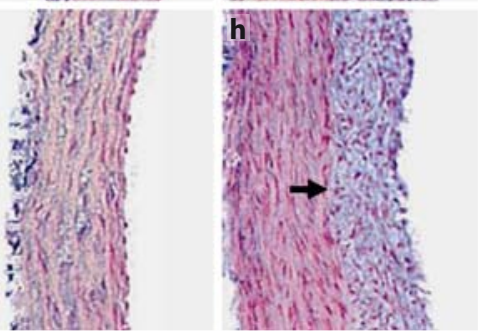

greater DHE fluorescence as compared to the adjacent medial layer, indicating increased ROS levels in the neointima (fig. la, b). The fluorescent signal was inhibited by both tiron and DPI treatment, which suggests a flavoenzyme-dependent mechanism of ROS generation, such as NADPH oxidase (fig. 1c, d). Further supporting this observation, the expression of the NADPH oxidase subunits $\mathrm{p} 47^{\text {phox }}$ and $\mathrm{p} 22^{\text {phox }}$ was increased in the neointima of the injured artery as compared to the adjacent medial layer and to the noninjured vessels (fig. le-h). The majority of cells in the neointima stained positive for $\alpha$-actin, indicating SMC origin (data not shown). These observations are consistent with previous findings [8] and suggest that, following balloon injury, neointimal SMCs have increased NADPH oxidase expression and activity.

To further examine the role of NADPH oxidase-derived superoxide in the neointima, SMCs were isolated from both the neointimal and medial layers of the injured aorta and studied in culture. Consistent with previous studies [3-6], these two distinct sources within the vascular wall provided SMCs with different morphologies, i.e. the neointimal cells exhibited an 'epithelioid' shape that differed from the 'spindle' shape morphology of the medial SMCs (fig. 2a). Neointimal SMCs expressed similar $\alpha$-actin and no smooth muscle myosin heavy chain (MHC) as compared to medial SMCs (fig. 2b). Similar to our findings in situ, intracellular ROS levels were greater in neointimal SMCs and inhibited by SOD (fig. 2c). This was not due to a reduction in neointimal SMC antioxidant capacity since cytosolic SOD and catalase activity were greater in neointimal SMC (CuZnSOD: $0.86 \pm 0.07$ and catalase: $0.68 \pm 0.18 \mathrm{medial} /$ neointimal SMC ratio, MnSOD: $1.38 \pm 0.09 ; \mathrm{n}=3$ ). The increased ROS levels were also inhibited by DPI (fig. 2c), consistent with $\mathrm{NADPH}$-derived superoxide (fig. 2c). NADPH oxidase activity was greater in membrane-enriched fractions prepared from neointimal SMCs as compared to medial SMCs (fig. 2d). Neointimal SMCs also displayed elevated cell growth in response to $0.1 \%$ serum as compared to medial SMCs, and this response was prevented with tiron (fig. 2e).

The observations of cell growth in the absence of a mitogen and increased NADPH oxidase activity led us to hypothesize that neointimal cells have increased expression of Nox1, a catalytic subunit of NADPH oxidase. This subunit has been shown to induce mitogen-independent cell growth [20]. Expression of Nox1 was higher in neointimal-derived SMCs as compared to medial SMCs (fig. 3a). In contrast, expression of Nox4, the other major catalytic NADPH oxidase subunit found in SMCs [13], was similar between these two vascular SMC subtypes (fig. 3b). We and others have reported that Nox1 expression is associated with ERK activity in SMCs and other cell types [18, 21-24]. Under quiescent conditions, neointimal but not medial SMCs demonstrated constitutive ERK1/2 phosphorylation, which was inhibited by treatment with tiron and DPI (fig. 3c, d). These data show that, under unstimulated conditions, neointimal cells have increased Nox1 expression and associated redox-dependent activation of ERK.

Degradation of the extracellular matrix by matrix metalloproteinase-9 (MMP-9) contributes to the development of neointima following carotid injury [25]. We pre- 


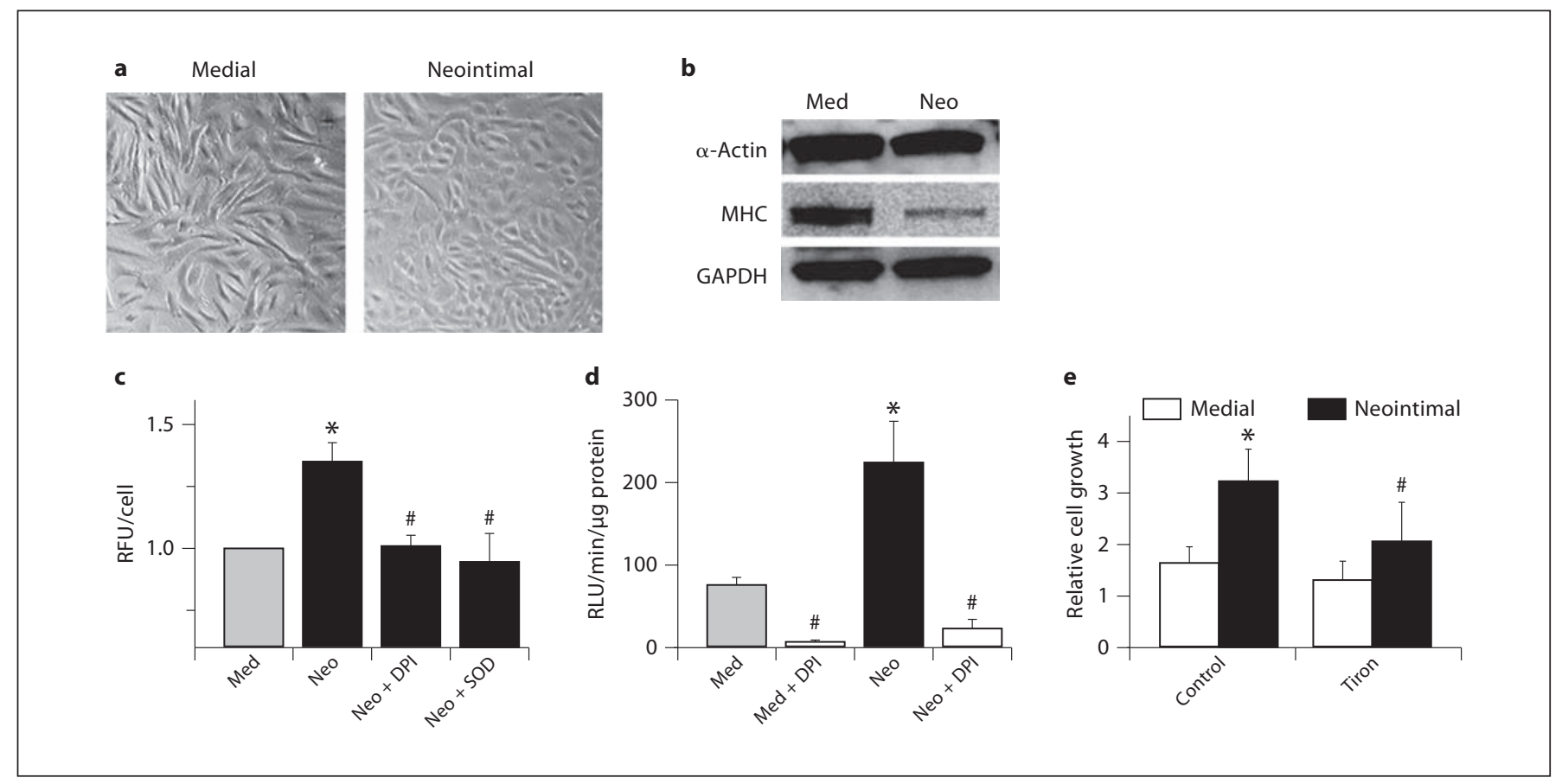

Fig. 2. NADPH oxidase activity is increased in neointimal-derived SMCs. a Phase micrographs of SMCs cultured from the medial and neointimal layers of balloon-injured thoracic aorta demonstrate different morphologies. b Expression of $\alpha$-actin, smooth muscle myosin heavy chain (MHC), and GAPDH in cultured medial (Med)- and neointimal (Neo)-derived SMCs. c ROS levels in cultured SMCs were assessed by flow cytometry after staining with DHE. Where indicated, neointimal SMCs were pretreated with DPI $\left(10^{-5} \mathrm{M}\right)$ or PEG-SOD (250 units/ml) prior to DHE staining. RFU $=$ Relative fluorescent units; $\mathrm{n}=4-6 . \mathbf{d} \mathrm{NADPH}$ $\left(10^{-4} \mathrm{M}\right)$-stimulated superoxide was measured by lucigenin-enhanced chemiluminescence in membrane-enriched cell fractions treated in the presence or absence of DPI $\left(10^{-5} \mathrm{M}\right)$. RLU = Relative light units; $\mathrm{n}=4-6$. e Cell growth in $0.1 \%$ serum was assessed by ${ }^{3} \mathrm{H}$-leucine incorporation. Where indicated, cells were pretreated with tiron $\left(10^{-4} \mathrm{M}\right)$ for $24 \mathrm{~h} ; \mathrm{n}=3$. $^{*} \mathrm{p}<0.05 \mathrm{vs}$. untreated medial SMCs; ${ }^{\#} \mathrm{p}<0.05$ vs. untreated neointimal SMCs.
Fig. 3. Nox1 expression and ERK1/2 activity are increased in neointimal SMCs. Expression of Nox1 (a) and Nox4 (b) at the mRNA level was measured by quantitative real-time PCR and copy number normalized to $18 \mathrm{~S}$ rRNA. ${ }^{*} \mathrm{p}<0.05$ vs. medial SMCs; $\mathrm{n}=4-5$. Neointimal and medial SMCs were pretreated with $10^{-4} \mathrm{M}$ tiron (c) or $10^{-5} \mathrm{M}$ DPI and cell lysates (d) collected after $24 \mathrm{~h}$ and analyzed by Western blot analysis for phospho-ERK1/2 and normalized to total ERK; $\mathrm{n}=4$. ${ }^{*} \mathrm{p}<0.05$ vs. medial SMC; ${ }^{\#} \mathrm{p}<0.05$ vs. no treatment.

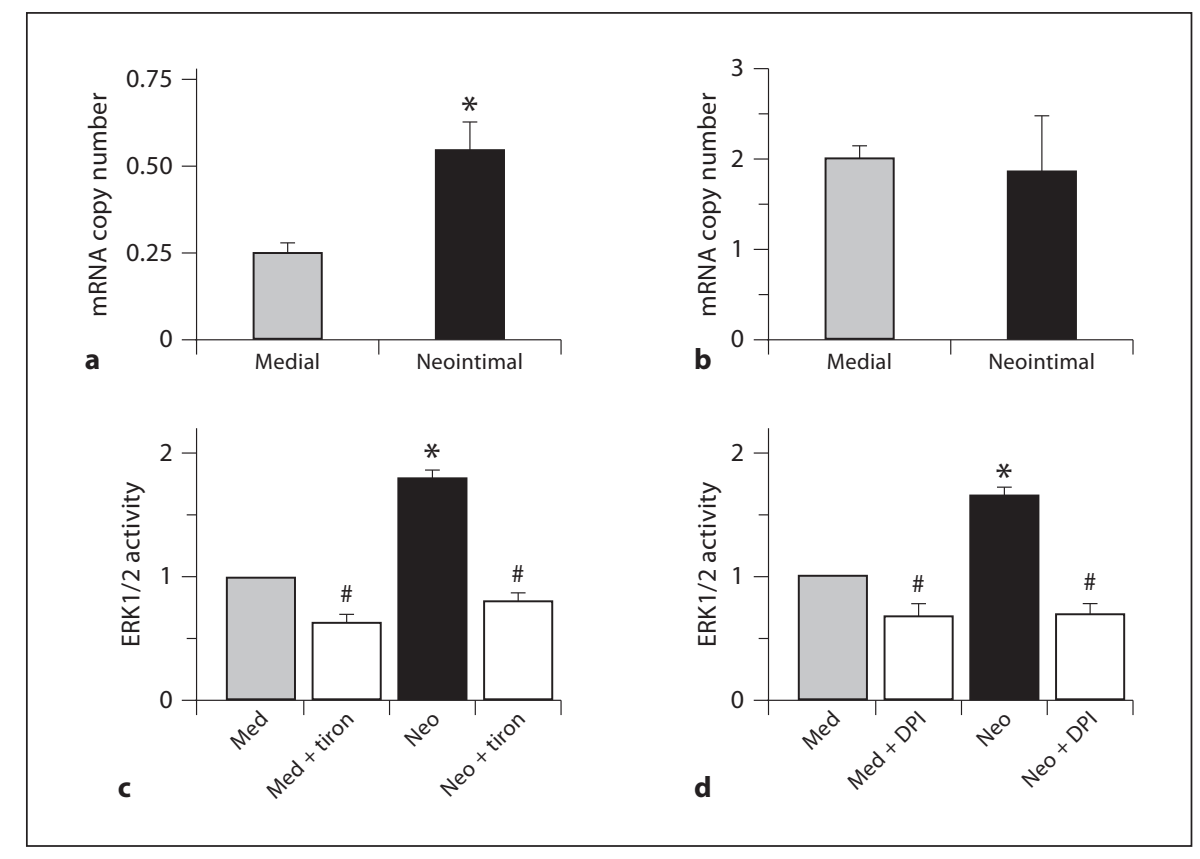




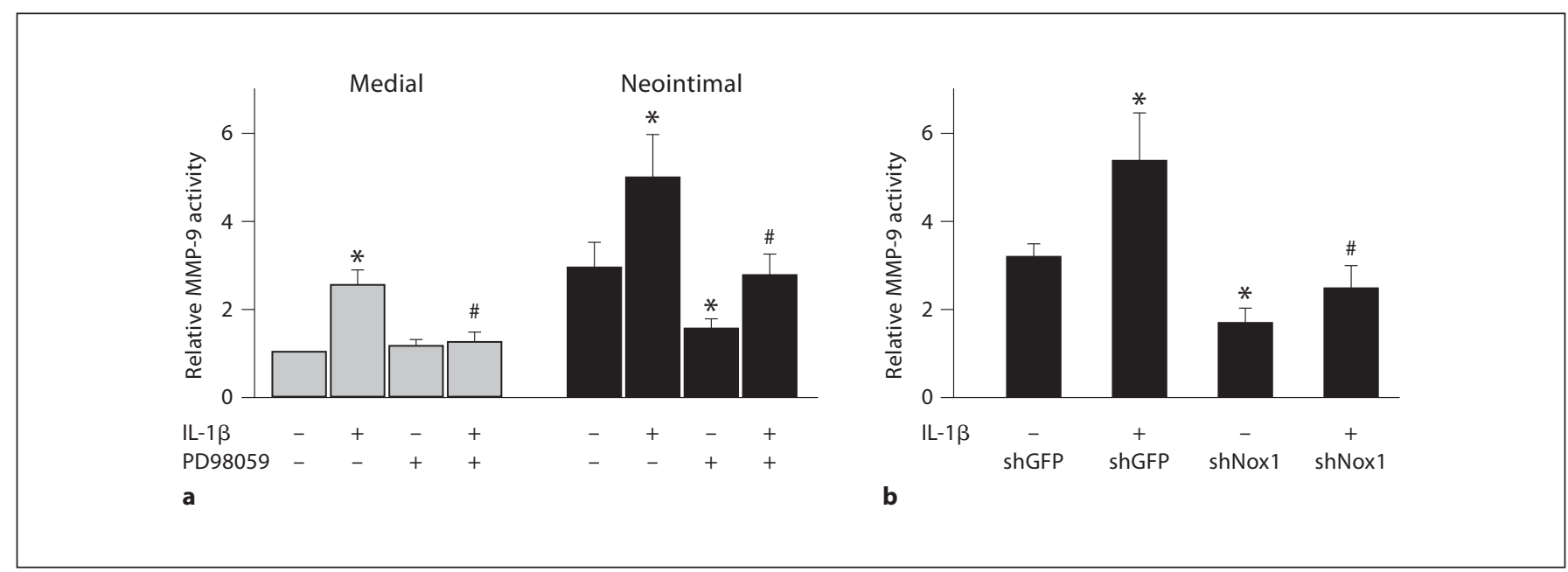

Fig. 4. MMP-9 activity is increased in neointimal SMCs and dependent on ERK1/2 activity and Nox1 expression. a Medial and neointimal SMCs were stimulated with IL-1 $\beta$ in the presence or absence of PD98059 $\left(10^{-5} \mathrm{M}\right)$ for $48 \mathrm{~h}$, the media was collected and MMP-9 activity measured by gelatin zymography, corrected for cell number, and then normalized to untreated medial SMCs. $\mathrm{n}=$
$6-8 .{ }^{*} \mathrm{p}<0.05$ vs. no treatment; ${ }^{*} \mathrm{p}<0.05$ vs. IL- $1 \beta$ treatment. b Neointimal SMCs were infected with an adenovirus expressing an shRNA against either Nox1 (shNox1) or GFP (shGFP). MMP-9 activity was assessed as in a. ${ }^{*} \mathrm{p}<0.05$ vs. shGFP no IL-1 $\beta$; ${ }^{*} \mathrm{p}<$ 0.05 vs. shGFP with IL-1 $\beta ; n=5$. viously found that activation of MMP-9 involves ROS and ERK signaling [17]. Conditioned media collected from quiescent intimal SMCs had greater MMP-9 activity than media from medial SMCs (fig. 4a). This increase in MMP-9 secretion was prevented by pretreatment with the ERK1/2 inhibitor PD98059 (fig. 4a) or with an shRNA against Nox1 [19] (fig. 4b). In addition, IL-1 $\beta$ stimulation of neointimal SMCs increased MMP-9 activity to a greater extent than in medial SMCs, an effect that was inhibited by pretreatment with PD98059 (fig. 4a). Similarly, expression of an shRNA to Nox1 prevented the effect of IL-1 $\beta$ on MMP-9 induction (fig. $4 b$ ). These data indicate that the increased MMP-9 activity in quiescent and activated neointimal cells is dependent on Noxl and ERK activation.

\section{Discussion}

Phenotypically distinct subsets of SMCs are activated and contribute to neointimal hyperplasia, yet the molecular characteristics that define the neointimal and medial SMCs are not fully understood. Herein, we demonstrate increased NADPH oxidase expression and activity in the neointimal layer in aortae after balloon injury. Furthermore, SMCs cultured from the neointima differ in morphology and growth as compared to medial SMCs. The neointimal SMCs have increased MMP-9 activity, which results in part from a greater Noxl expression and ERK activation in these cells. Our results provide a molecular basis for the phenotypic changes observed following vascular injury and implicate Nox1 as an important mediator of neointimal SMC activation.

Our findings of increased ROS in the neointima of the injured vessel are consistent with the pathologic role of ROS since antioxidants prevent intimal formation [26]. The NADPH oxidases have been identified as the primary source of ROS in blood vessels [13]. Expression of the Nox1 NADPH oxidase in the intima is increased early after wire injury, whereas expression of Nox4 remains at normal levels until late in the development of the neointima [8]. Furthermore, mice deficient in Nox1 have less neointimal hyperplasia in the femoral artery after wire injury as compared to wild-type mice [27], further supporting a direct role for Nox1 in SMC activation. We confirmed the increased expression and activity of NADPH oxidase in the neointima in vivo, validating a role for Nox1-derived ROS in restenosis. We extended these findings by showing increased Nox1 expression and ROS levels in cultured SMCs derived from the neointima following aortic injury. Therefore, the neointimal phenotypic characteristics are preserved in vitro. 
The formation of the neointima following injury is complex and requires activation of cellular processes involving multiple cell types. Within the medial layer, these processes include matrix degradation by metalloproteinases, thereby allowing migration of SMCs to the subendothelial space and proliferation to form the neointima. With our findings, Nox1 is now implicated in each step of this process. Herein, we show that MMP-9 activity in the neointimal-derived SMCs is increased compared to medial SMCs, and this effect is dependent on the expression of Nox1. Furthermore, migration to basic fibroblast growth factor and to platelet-derived growth factor is impaired in Nox1-deficient SMCs [27, 28]. Finally, expression of Noxl is sufficient to induce mitogenic activity [20], and Nox1 null SMCs have decreased rates of growth [27]. In accordance with these observations, we found that neointimal cells had increased serum-independent growth that was prevented by antioxidant. Taken together, these data identify Nox1 as a central mediator in the development of neointimal hyperplasia.

There are several potential mechanisms by which Nox1-derived ROS activate SMCs [29]. Modification of redox-sensitive residues leads to activation of kinases and/or inactivation of phosphatases. These Nox1-dependent changes in turn modulate migration through cytoskeletal remodeling, activation of adaptor proteins, and regulation of adhesion molecules. Nox1 also controls cell growth via activation of cell cycle proteins and transcription factors. Recently, it has been shown that Nox1-derived ROS activate ERK1/2 with a subsequent increase in Nox1 expression [24]. Similarly, we found that neointimal-derived SMCs have increased ERK1/2 activation associated with elevated Nox 1 expression. Our data suggest that ERK1/2 phosphorylation in neointimal cells is activated by NADPH oxidase-generated ROS.

Redox-dependent activation of ERK results in induction of MMP-9 in SMCs [17]. We extend these observations by showing that, in neointimal SMCs, ERK is responsible for the increased MMP-9 activity. Furthermore, IL-1 $\beta$ activation of MMP-9 is Nox1-dependent. MMP-9 activity is an important determinant of vascular disease, contributing to plaque development and instability in atherosclerosis [30,31].

One of the interesting observations from this study is the autonomous increase in ROS levels and ERK and MMP-9 activation in neointimal SMCs. The epithelioid neointimal-derived SMCs are known to have an increased proliferative rate as compared to spindle-shaped medial cells $[5,32]$. The origin of these different morphologies appears to already exist as subpopulations of
SMCs within the medial layer. For example, SMCs in the subendothelial region of larger arteries demonstrate constitutive ERK activity and serum-independent growth unlike SMCs from the middle media [33]. It is not known whether there are differences in Nox 1 expression in these distinct subtypes of SMCs within the media. Although many of these phenotypic effects have been attributed to Noxl, differentiation of SMCs is regulated by Nox4 and not Nox1 [34]. The complex interaction between these two SMC-derived NADPH oxidase subunits requires further investigation.

In summary, these findings highlight the role of Noxl in mediating the SMC response to injury. The therapeutic targeting of Nox1 or its redox-dependent signaling may reduce arterial remodeling associated with vascular disease.

\section{Acknowledgements}

The authors wish to thank their associates at the University of Iowa, Roy J. and Lucille A., the Carver College of Medicine Central Microscopy Research Facility and the Gene Transfer Vector Core Facility of the University of Iowa Center for Gene Therapy of Cystic Fibrosis and Other Genetic Diseases (supported by NIH/ NIDDK P30 DK 54759). The material in this study is based upon work supported in part by the Office of Research and Development, Department of Veterans Affairs (F.J.M.) and by NIH grant HL081750 (F.J.M.). N.L.W. currently works at the Department of Internal Medicine and the VA Medical Center, University of Cincinnati College of Medicine. We thank Kristina W. Thiel for her editing assistance.

References
Schwartz SM, deBlois D, O’Brien ER: The intima. Soil for atherosclerosis and restenosis. Circ Res 1995;77:445-465.

2 Walker LN, Bowen-Pope DF, Ross R, Reidy MA: Production of platelet-derived growth factor-like molecules by cultured arterial smooth muscle cells accompanies proliferation after arterial injury. Proc Natl Acad Sci USA 1986;83:7311-7315

- 3 Li WG, Miller FJ Jr, Brown MR, Chatterjee P, Aylsworth GR, Shao J, Spector AA, Oberley LW, Weintraub NL: Enhanced H(2)O(2)-induced cytotoxicity in 'epithelioid' smooth muscle cells: implications for neointimal regression. Arterioscler Thromb Vasc Biol 2000;20:1473-1479.

4 Frid MG, Aldashev AA, Dempsey EC, Stenmark KR: Smooth muscle cells isolated from discrete compartments of the mature vascular media exhibit unique phenotypes and distinct growth capabilities. Circ Res 1997; 81:940-952. 
5 Orlandi A, Ehrlich HP, Ropraz P, Spagnoli LG, Gabbiani G: Rat aortic smooth muscle cells isolated from different layers and at different times after endothelial denudation show distinct biological features in vitro. Arterioscler Thromb 1994;14:982-989.

-6 Chiavegato A, Giuriato L, Scatena M, Sartore S: Heterogeneity of smooth muscle in bovine coronary arteries. Cardioscience 1993;4:7584.

7 Souza HP, Souza LC, Anastacio VM, Pereira AC, Junqueira ML, Krieger JE, da Luz PL, Augusto O, Laurindo FR: Vascular oxidant stress early after balloon injury: evidence for increased $\mathrm{NAD}(\mathrm{P}) \mathrm{H}$ oxidoreductase activity. Free Radic Biol Med 2000;28:1232-1242.

8 Szocs K, Lassegue B, Sorescu D, Hilenski LL, Valppu L, Couse TL, Wilcox JN, Quinn MT, Lambeth JD, Griendling KK: Upregulation of Nox-based NAD $(\mathrm{P}) \mathrm{H}$ oxidases in restenosis after carotid injury. Arterioscler Thromb Vasc Biol 2002;22:21-27.

-9 Jackson CL, Pettersson KS: Effects of probucol on rat carotid artery responses to balloon catheter injury. Atherosclerosis 2001;154: 407-414.

-10 Shi Y, Niculescu R, Wang D, Patel S, Davenpeck KL, Zalewski A: Increased $\mathrm{NAD}(\mathrm{P}) \mathrm{H}$ oxidase and reactive oxygen species in coronary arteries after balloon injury. Arterioscler Thromb Vasc Biol 2001;21:739-745.

- 11 Jacobson GM, Dourron HM, Liu J, Carretero OA, Reddy DJ, Andrzejewski T, Pagano PJ: Novel NAD(P)H oxidase inhibitor suppresses angioplasty-induced superoxide and neointimal hyperplasia of rat carotid artery. Circ Res 2003;92:637-643.

12 Galis ZS, Khatri JJ: Matrix metalloproteinases in vascular remodeling and atherogenesis: the good, the bad, and the ugly. Circ Res 2002;90:251-262.

13 Lassegue B, Griendling KK: NADPH oxidases: functions and pathologies in the vasculature. Arterioscler Thromb Vasc Biol 2010;30: 653-661.

14 Clowes AW, Reidy MA, Clowes MM: Kinetics of cellular proliferation after arterial injury. I. Smooth muscle growth in the absence of endothelium. Lab Invest 1983;49:327-333.

15 Miller FJ Jr, Gutterman DD, Rios CD, Heistad DD, Davidson BL: Superoxide production in vascular smooth muscle contributes to oxidative stress and impaired relaxation in atherosclerosis. Circ Res 1998;82:12981305.
16 Miller FJ Jr, Griendling KK: Functional evaluation of nonphagocytic $\mathrm{NAD}(\mathrm{P}) \mathrm{H}$ oxidases. Methods Enzymol 2002;353:220-233.

-17 Gurjar MV, Deleon J, Sharma RV, Bhalla RC: Role of reactive oxygen species in IL-1 betastimulated sustained ERK activation and MMP-9 induction. Am J Physiol Heart Circ Physiol 2001;281:H2568-H2574.

18 Stanic B, Katsuyama M, Miller FJ Jr: An oxidized extracellular oxidation-reduction state increases Nox1 expression and proliferation in vascular smooth muscle cells via epidermal growth factor receptor activation. Arterioscler Thromb Vasc Biol 2010;30: 2234-2241.

19 Miller FJ Jr, Chu X, Stanic B, Tian X, Sharma RV, Davisson RL, Lamb FS: A differential role for endocytosis in receptor-mediated activation of Nox1. Antioxid Redox Signal 2010;12:583-593.

20 Suh YA, Arnold RS, Lassegue B, Shi J, Xu X, Sorescu D, Chung AB, Griendling KK, Lambeth JD: Cell transformation by the superoxide-generating oxidase Mox1. Nature 1999; 401:79-82.

-21 Cevik MO, Katsuyama M, Kanda S, Kaneko T, Iwata K, Ibi M, Matsuno K, Kakehi T, Cui W, Sasaki M, Yabe-Nishimura C: The AP-1 site is essential for the promoter activity of NOX1/NADPH oxidase, a vascular superoxide-producing enzyme: possible involvement of the ERK1/2-JunB pathway. Biochem Biophys Res Commun 2008;374:351-355.

22 Adachi Y, Shibai Y, Mitsushita J, Shang WH, Hirose K, Kamata T: Oncogenic Ras upregulates NADPH oxidase 1 gene expression through MEK-ERK-dependent phosphorylation of GATA-6. Oncogene 2008;27:49214932.

23 Komatsu D, Kato M, Nakayama J, Miyagawa S, Kamata T: NADPH oxidase 1 plays a critical mediating role in oncogenic Ras-induced vascular endothelial growth factor expression. Oncogene 2008;27:4724-4732.

24 Sancho P, Fabregat I: NADPH oxidase NOX1 controls autocrine growth of liver tumor cells through up-regulation of the epidermal growth factor receptor pathway. J Biol Chem 2010;285:24815-24824.

25 Cho A, Reidy MA: Matrix metalloproteinase-9 is necessary for the regulation of smooth muscle cell replication and migration after arterial injury. Circ Res 2002;91: 845-851.
26 Kappert K, Sparwel J, Sandin A, Seiler A, Siebolts U, Leppanen O, Rosenkranz S, Ostman A: Antioxidants relieve phosphatase inhibition and reduce PDGF signaling in cultured VSMCs and in restenosis. Arterioscler Thromb Vasc Biol 2006;26:2644-2651.

-27 Lee MY, Martin AS, Mehta PK, Dikalova AE Garrido AM, Datla SR, Lyons E, Krause K-H, Banfi B, Lambeth JD, Lassegue B, Griendling KK: Mechanisms of vascular smooth muscle NADPH oxidase 1 (Nox1) contribution to injury-induced neointimal formation. Arterioscler Thromb Vasc Biol 2009;29:480-487.

-28 Schroder K, Helmcke I, Palfi K, Krause KH Busse R, Brandes RP: Nox1 mediates basic fibroblast growth factor-induced migration of vascular smooth muscle cells. Arterioscler Thromb Vasc Biol 2007;27:1736-1743.

29 Brown DI, Griendling KK: Nox proteins in signal transduction. Free Radic Biol Med 2009;47:1239-1253.

30 Choi ET, Collins ET, Marine LA, Uberti MG, Uchida H, Leidenfrost JE, Khan MF, Boc KP Abendschein DR, Parks WC: Matrix metalloproteinase- 9 modulation by resident arterial cells is responsible for injury-induced accelerated atherosclerotic plaque development in apolipoprotein E-deficient mice. Arterioscler Thromb Vasc Biol 2005;25: 1020-1025

31 de Nooijer R, Verkleij CJ, von der Thusen JH, Jukema JW, van der Wall EE, van Berkel TJ, Baker AH, Biessen EA: Lesional overexpression of matrix metalloproteinase- 9 promotes intraplaque hemorrhage in advanced lesions but not at earlier stages of atherogenesis. Arterioscler Thromb Vasc Biol 2006;26:340346

32 Myit S, Delafontaine P, Bochaton-Piallat ML, Giraud S, Gabbiani G, Brink M: Different growth properties of neointimal and medial smooth muscle cells in response to growth factors. J Vasc Res 2003;40:97-104.

-33 Frid MG, Aldashev AA, Nemenoff RA, Higashito R, Westcott JY, Stenmark KR: Subendothelial cells from normal bovine arteries exhibit autonomous growth and constitutively activated intracellular signaling. Arterioscler Thromb Vasc Biol 1999;19:28842893.

34 Clempus RE, Sorescu D, Dikalova AE, Pounkova L, Jo P, Sorescu GP, Schmidt HH, Lassegue B, Griendling KK: Nox4 is required for maintenance of the differentiated vascular smooth muscle cell phenotype. Arterioscler Thromb Vasc Biol 2007;27:42-48. 